\title{
Greek Texts and the Rigorization of Analysis: An Inquiry into J. L. Lagrange's Work on the History of Mathematics
}

\author{
Wang Xiaofei 王晓斐1
}

(Institute for the History of Natural Sciences, Chinese Academy of Sciences, Beijing 100190, China)

\begin{abstract}
This paper offers a study of J. L. Lagrange's research on history of mathematics, aiming to clarify Lagrange's intention in carrying out historical work. To this end, I first document how Lagrange worked with and exerted his influence on other scholars in the translation and diffusion of ancient Greek texts. Second, investigating Lagrange's style in doing and writing history of mathematics, this paper takes a new perspective and elucidates his motivation in these activities. In particular, it focuses on Lagrange's presentation of the history of calculus while he was teaching analysis at the Ecole Polytechnique (1795-1799) so as to clarify the function of history in Lagrange's mathematical works. My thesis is that Lagrange's intention in examining the different methods employed by his predecessors was to find inspiration and useful contents in his search for the proper approach to mathematical problems. I thus argue in this paper that history served as a guide or methodology for Lagrange's mathematics. Meanwhile, through an analysis of his historical writing, this paper points to four epistemological values according to which Lagrange judged various historical methods of differential calculus: generality, simplicity, clarity, and rigor. Lagrange's move to rigorize analysis was connected to his interest in and research of Greek texts; he was attempting to introduce the rigor of the ancient Greeks' demonstration in his works of analysis.
\end{abstract}

Keywords: ancient Greek mathematics, history of calculus, Ecole Polytechnique, epistemological values, rigorizing analysis

摘 要: 本研究关注拉格朗日在数学史方面的兴趣及工作, 并旨在澄清拉格朗日研究历 史的意图。通过对不同史料的分析, 首先, 本文论述了拉格朗日在翻译和传播古希腊数 学著作中所发挥的作用及其与欧几里得《几何原本》以及托勒密《至大论》的法文翻译 者之间的联系和对他们的影响; 其次, 本文以新的角度并利用新的材料重申和强调了拉 格朗日研究数学史的方式和动机; 最后, 以拉格朗日的微积分的历史书写为案例, 本文 阐明了历史在其数学工作中发挥的作用。本文的结论有以下几点: 拉格朗日对历史研究

* The paper was copyedited by Charlie Zaharoff.

1 Research interest: History of mathematics. Email: xiaofei.wang@ihns.ac.cn 
的目的是从中获取其前人解决某一数学问题所使用的所有不同的方法, 从而找出使其突 破该问题的新的或合适的方法。因而, 本文强调历史在拉格朗日的工作中所扮演的角色 是其指导和方法论; 同时, 本文揭示了拉格朗日在其分析学著作中追求的四项认识论价 值, 即一般性、简单性、清晰性和严格性, 并且说明这些价值是作为其发现合适的微积分 方法所秉持的标准。因而在这一意义上, 拉格朗日早于柯西已然展开了数学分析的严格 化。这一工作亦是与其对古希腊数学著作的兴趣有联系的, 因为他声明并试图在其分析 著作中引入古希腊证明中的严格性。

关键词: 古希腊数学著作, 微积分史, 巴黎综合理工学院, 认识论价值, 分析严格化

\section{Introduction}

$\mathrm{U}^{\mathrm{s}}$ ntil the nineteenth century, history of sciences was seen as a demonstration of the progress of the sciences, and hence of the human mind. J. L. Richard suggests that in the eighteenth century, the history of mathematics was considered the best way to appreciate the story of human progress (Richard 2006, 702). It also drew attention to a number of savants ${ }^{2}$ who simultaneously worked in a scientific domain and showed great interest in historical work. In 1758, the French mathematician and historian Jean-Etienne Montucla (1725-1799) published a two-volume work titled L'Histoire des mathématiques (History of Mathematics), in which the author considered the progress of mathematics from its origins until his day. He began the book as follows:

One of the spectacles most likely to be of interest to the philosophical eye is indisputably that of the development of the human spirit, and the different branches of their knowledge. (Montucla 1758, iii) ${ }^{3}$

The author thus regretted that the history of mathematics, in his mind as important as other forms of human knowledge, had been neglected for such a long time. In his view, the history of science was useful, capable even of contributing to its progress, if it could be done in a certain way. Montucla described this as follows:

(But) if someone, going back to the origin of a science, following the development from one age to the next, presents the overview and the spirit of all the discoveries that successively enriched it, and by this means displays the part of glory or of esteem due to each of those who cultivated it; and if, in doing so, he indicates to the reader the best sources one should go to, and through a well-done presentation of these discoveries and the views that yielded them, often liberates the reader from the necessity to go back to the

2 I borrow this word from a work by the historian B. Belhoste, according to whom a savant refers to a scientist in the broadest sense, including academicians, professors, and people who in some other way contribute to science. See Belhoste (2011).

3 "Un des spectacles les plus dignes d'intéresser un œil philosophique, est sans contredit celui du développement de l'esprit humain, and des différentes branches de ses connoissances [connaissances]." 
sources, who can doubt that this constitutes an important help to all those who are engaged in the career of this science, leading them along an easy and agreeable road to the point they aim to reach, finally helping them save their energy and allowing them to move further. (Montucla 1758, v)

Such an opinion about the history of science, and the history of mathematics in particular, was likely shared by most scientists of the eighteenth century. Then as now, mathematicians are generally interested in the history of the disciplines in which they are active, as such sources undoubtedly benefit their work.

However, few studies have been done on this subject, that is, how past mathematicians dealt with history and for what purpose. As a case study, this paper will consider J. L. Lagrange's works related to the history of mathematics. It aims to show Lagrange's work in the history of mathematics and his support for translating and disseminating ancient Greek mathematical texts, as well as how such efforts were connected to his own mathematical works.

Several historians have remarked on Lagrange's interest in the history of mathematics, but only a few have clarified Lagrange's motivation to introduce historical accounts into his mathematical works. In Writing the History of Mathematics: Its Historical Development, J. Peiffer provides an outline of the historiography of mathematics in France from the Renaissance to the nineteenth century. She analyzes the evolving attitude towards ancient works, mainly the works of ancient Greeks, and the motivations to reestablish these works since the Renaissance. At the end of her chapter, the author talks about the historical writings which appeared in the works of nineteenth-century mathematicians like Lagrange and Laplace and characterizes their approaches to the history of mathematics as whiggish (Peiffer 2002, 25). ${ }^{5}$

R. Rashed has contributed an article on Lagrange's reading of Diophantus's Arithmetica. He remarks on Lagrange's interest in the analysis of Diophantus, and that in several memoirs in the domain of the theory of numbers, Lagrange started his investigation with outlines of the history of the problems to be solved (Rashed 1988, 39). Moreover, he underlines the fact that Lagrange conceived a project to produce a new

4 “(Mais) si quelqu'un, remontant à l'origine d'une science, en suivoit [suivait] le développement d'âge en âge, présentoit [présentait] le tableau et l'esprit de toutes les découvertes qui l'ont successivement enrichie, et faisoit connoître [connaître] par ce moyen la part de gloire ou d'estime dûe à chacun de ceux qui l'ont cultivée; si, chemin faisant, il indiquoit au lecteur les meilleures sources où il doit puiser, si par un exposé bien fait de ces découvertes, et des vues qui y ont conduit, il l'affranchissoit [l'affranchissait] souvent de la nécessité de recourir à ces sources, qui peut douter que ce ne fût rendre un service marqué à tous ceux qui courent la carriere de cette science; les conduire par un chemin facile et agréable, au terme qu'ils se proposent; enfin ménager, pour ainsi dire, leurs forces, et les mettre en état d'aller plus facilement au delà."

5 According to the editors of the same book, the whiggish views of the nineteenth-century historiography of mathematics embraced a vision of human progress. See Dauben et al. (2002, $x x i)$. 
edition of Arithmetica. Through his investigation, Rashed points out that in Lagrange's view, both the work by Fermat on the theory of numbers and Diophantus's Arithmetica offered "useful methods" to mathematicians. Also, he emphasizes that Lagrange's intention was to translate Diophantus's work in an algebraic manner so as to bring out methods that were worthy of the attention of contemporary mathematicians. Rashed thus concludes that for Lagrange, as well as for eighteenth-century mathematicians in general, history constituted a part of mathematical research (Rashed 1988, 47).

A. Oliveira has written an interesting article titled "Lagrange as a Historian of Mechanics," in which he provides a study on the details of the history of mechanics that Lagrange presented in the preface of the Mecanique analytique (Analytic Mechanics) in 1788. ${ }^{6}$ In his paper, A. Oliveira suggests that Lagrange's aim was to find some basic fundamental principles which could fit all natural phenomena, a search that he conducted by analyzing the historical development of three concepts: "the equilibrium of the lever; the composition of motions; virtual velocities" (Oliveira 2013, 130).

These studies lend strong support to my thesis. However, in order to provide a clearer and more complete picture of Lagrange's historical enterprises and to reveal how history functioned in Lagrange's mathematical works, this paper will consider new documents that demonstrate Lagrange's strong interest in Greek texts and his support for the French translators of Euclid's Elements and Ptolomy's Almagest. Furthermore, it will give a thorough analysis of the history of calculus that Lagrange presented at the beginning of his two important works of analysis, that is, Théorie des fonctions analytiques (Analytic Theory of Functions) and Leçons sur le calcul des fonctions (Lectures on Calculus of Functions), ${ }^{7}$ in order to clarify the ways in which history appeared and functioned in Lagrange's mathematical works.

The paper has three sections. First, I will interpret Lagrange's interest in ancient Greek mathematical texts as well as the role that he played in the translation and diffusion of these texts. In order to understand and explain Lagrange's intention to ensure good translations of mathematical texts of the ancients, I focus on Lagrange's historiographical style, which was noticed by one of his contemporaries, the Italian mathematician and historian Guillaume Libri (1803-1869). Therefore, the second section of this paper is devoted to a study of Libri's article, published in 1839 in the Journal des savants, about Lagrange's great interest in ancient works and his project of producing a new edition of Diophantus's Arithmetica. Through this investigation, I will

6 The second edition of this work appeared in 1798. One can also consult CEuvre de Lagrange, tome 11 .

7 They were first published in 1797 and 1801, respectively, and both were published twice. Besides, they appeared as tomes 9 and 10 in CEuvre de J. L. Lagrange. This paper consults mainly the first editions of these two works. More details on them will be given in the third part of this article. 
clarify that Lagrange's interest was in the methods applied in the historical texts of mathematics. Finally, by analyzing Lagrange's history of calculus specifically, I demonstrate that in this case, history functioned as a methodology for Lagrange in his search for appropriate methods which can meet certain standards. Such standards conform to the four epistemological values Lagrange pursued in his own works of analysis: generality, simplicity, rigor, and clarity. The rigor that Lagrange was motivated to introduce in his work of analysis, as he emphasized, is in accordance with that of the ancient Greeks.

\section{The translation and diffusion of Greek texts}

As G. Aujac has remarked, the translations in French of the most important texts of Greek science, in particular astronomy, geometry, and geography, came out in a span of less than twenty years (Aujac 1990, 395). From 1804 to 1818, translations and publications of the works of the most important Greek authors, such as Euclid, Archimedes, and Ptolemy, appeared in France. These Greek texts were translated and studied by a group of scholars that included François Peyrard (1760-1822) and Nicolas Halma (1755-1828), who respectively translated Euclid's Elements and Ptolemy's Almagest or Mathematical Composition. Interestingly, they were all connected to the Ecole Polytechnique. In fact, the Ecole Polytechnique served as the venue where these scholars gathered and worked on their project of translating mathematical texts by the ancient Greek authors, such as Euclid, Ptolemy, Apollonius, and Diophantus. We know that Lagrange taught at this school from 1795 to 1799. And certainly he had connections with Peyrard and Halma when the latter two undertook their project at the Ecole Polytechnique. One may wonder if Lagrange played a role in the project of disseminating Greek texts. In this section, based on new materials, I will clarify this issue.

As a matter of fact, Lagrange took a special interest in ancient Greek mathematics. As a result of the French Revolution, Lagrange became a professor of mathematics and gave lectures first at the Ecole Normale of the Year III and then at the Ecole Polytechnique. ${ }^{8}$ In his teaching, Lagrange provided many historical details. He presented the progress that had been made by past inventors and mathematicians as well as the techniques they had employed to overcome difficulties. Lagrange was capable of giving these lectures in a narrative form, for he had abundant knowledge on

8 These first lectures at the Ecole Normale of the Year III were published in 1800 in Séances des Ecole normales, recueillies par des sténographes et revues par les professeurs, and then again in 1812 in Journal de l'Ecole Polytechnique. One can also consult Dhombres (1992). Lagrange repeated these lectures on arithmetic and algebra at the Ecole Polytechnique before he began the subject of differential calculus. For a description of Lagrange's lectures at the Ecole Polytechnique, see Prony $(1796,206-208)$. 
the history of mathematics. ${ }^{9}$ In his first lectures on the subject of arithmetic, in speaking of the decimal place-value system, which he considered the essence of modern arithmetic, Lagrange conveyed his curiosity about the way in which the ancients expressed numbers and executed arithmetic operations. Also, because of his appreciation for Diophantus's work, he expressed his regret that there was no good French translation of this important work. On this occasion, Lagrange said:

It should be hoped that we produce in the French language good translations not only of the work of Diophantus, but also of the small number of mathematical works that the Greeks bequeathed to us. (Dhombres 1992, 223)10

Certainly, as a renowned mathematician, Lagrange's course attracted young teachers and students at the Ecole Polytechnique. Indeed, Lagrange's teaching, which was threaded with histories, impressed his colleagues. Jean-Guillaume Garnier (1766-1840), who was the assistant of Lagrange at the Ecole Polytechnique from 1798 to 1802, credited Lagrange as one of the most erudite scholars on the history of mathematics. As indicated in his autobiography, Garnier borrowed Lagrange's telling of the history of science for his books (Quetelet 1839, 194).

François Peyrard (1760-1822), the librarian of the Ecole Polytechnique from 1795 until 1804, entered the school at the same time Lagrange started teaching there. According to Peyrard, he had previously played a role in the organization of public education in 1793, working together with Lagrange and Gaspard Monge (1746-1818) as active members of the commission charged by the Department of Paris to design a system of public education (Langins 1989, 4). He was thus in touch with both of them and soon became their colleague at the Ecole Polytechnique.

As librarian, Peyrard devoted himself to the management of the library. During his term, he not only expanded the number of the volumes collected in the library from one thousand to ten thousand, he also turned the library into a place of research for savants (Langins 1989, 5). He probably regarded himself not only as a librarian but as a savant in his own right, whose task was to contribute to research or studies that would advance the sciences and arts ${ }^{11}$. Since his youth, Peyrard cultivated his interest in both the sciences and classic literature. At the Ecole Polytechnique, Peyrard devised and initiated the enterprise of translating important ancient Greeks texts. Undoubtedly, the

$9 \mathrm{~J}$. Richard has argued that a tradition of narrative mathematics was preferred by eighteenth-century mathematicians like Lagrange and his mentor, Jean le Rond D'Alembert (1717-1783). See Richard (2006).

10 "Il serait à souhaiter qu' on fit passer dans la langue française par de bonnes traductions non seulement l'ouvrage de Diophante, mais encore le petit nombre d'ouvrages mathématiques que les Grecs nous ont laissés."

11 The word "arts" in the eighteenth century referred to crafts and applied arts, so it is close to "technology" in modern times. 
library of the Ecole Polytechnique, where "almost all the good ancient and modern books related to sciences and arts" were preserved with Peyrard's efforts (Langins 1989, 5), provided quite a good environment for the instituteurs (the former name of professors in France) of the school to fulfill their roles.

Certainly, Peyrard and his enterprise of translating ancient Greek texts benefited from this institutional situation. From 1793 to 1804, he published or translated several treatises in disciplines ranging from philosophy and history to literature and the sciences. In 1804, Peyrard published a French translation of the Elements of Geometry by Euclid. In the preface of this book, Peyrard spoke of the project that he had initiated at the Ecole Polytechnique:

When I was appointed as the librarian of the Ecole Polytechnique, I formed the project to give the public a literal translation of the complete works of Euclid and Archimedes, the two greatest geometers of antiquity. I thought that it was sort of my duty to devote my spare time to work that was in line with that of the Ecole Polytechnique. (Peyrard 1804, ix $)^{12}$

This indicates that the Ecole Polytechnique was the place where Peyrard initiated the project of translating the mathematical works of two of the most important Greek mathematicians, Euclid and Archimedes. In Peyrard's view, such a project was a good fit for the school. In a meeting on June 8, 1804, when Peyrard suggested obtaining a good copy of Archimedes's work, the members of the Council of the Ecole Polytechnique discussed how the translations of Greek and Latin texts could be useful: ${ }^{13}$

The decision to purchase a copy of the Oxford edition of Archimedes for the library (the action suggested by Peyrard) [would provide] several members with the opportunity to develop the benefits for the utility of students, the advancement of exact sciences, and the glory of the school, if according to a regular and well-thought-out plan, [the school] managed to obtain translations of the ancient Greek and Latin authors, on which the professors of the school would work together with the most learned men of letters in order to establish the genuine text, rendering it faithfully by adding necessary or interesting notes that the most immediate study of these authors would provide.

12 “Lorsque je fus nommé Bibliothécaire de l'Ecole polytechnique, je formai le projet de donner au public une traduction littérale des œuvres d'Euclide et d'Archimède, les deux plus grands Géomètres de l'antiquité. Je pensois qu'il étoit [était] en quelque sorte de mon devoir de consacrer mes momens [moments] de loisir à des travaux qui fussent analogues à ceux de l'Ecole polytechnique."

13 This discussion was recorded in the transcripts of the meetings of the Council of the Ecole Polytechnique, and mentioned in Langins (1989). 
(Langins 1989, 7) $)^{14}$

Here we see that translations of classic works of mathematics were in demand at the Ecole Polytechnique. Teachers of the school were encouraged to work together to produce genuine translations of the ancient authors, which would be useful for students as well as advance the state of science and the reputation of the school.

Certainly, Lagrange was a member of the council of the school. He must have attended the aforementioned meeting. And as I have mentioned before, it was also at the Ecole Polytechnique that Lagrange demonstrated his great interest in the production of good translations of important ancient Greek mathematical texts. All the teachers and students were called to attend Lagrange's inaugural lecture, in which he presented the elements of arithmetic (Prony 1796, 206). Peyrard might have been in attendance at Lagrange's lecture, compelling him to undertake his project of translation. In this way, his mastery of the Greek language could be of use to the school.

Indeed, in his works, Peyrard mentioned Lagrange's help and encouragement several times either implicitly or explicitly. After first contributing to the French translation of Books I, II, III, IV, XI, and XII of the Elements by Euclid, he published a translation of the complete work of Archimedes in 1807. In the latter, Peyrard indicated that he had also been asked by several members of the Class of Physical and Mathematical Sciences of the institute to produce a translation of Apollonius's work (Peyrard 1807, xxxvii). Indeed, the mathematician Lagrange and the astronomer Jean-Baptiste Delambre (1749-1822) were among those who requested it. Both of the two, as representatives of the National Institute of France, had approved Peyrard's translation of the Elements by Euclid. In their report (which was put at the beginning of Peyrard's translation), Lagrange and Delambre expressed their opinion of Peyrard's project:

we can conclude at least from their opinion [that considers Euclid's Elements to be the best work available for learning the ancient methods], that Peyrard has done useful work in faithfully translating a work of which we haven't had an exact translation for more than two hundred years, and of which the good editions, either in Greek or in Latin, are rare and can be reached by few scholars, without taking into account the difficulties of the two languages, which still diminish considerably the number of readers. (Peyrard

14 "La délibération d'acheter un exemplaire de l'édition d'Archimède d'Oxford pour la bibliothèque (action suggérée par Peyrard) fournit à plusieurs membres l'occasion de développer les avantages qui résulteraient pour l'utilité des élèves, pour l'avancement des sciences exactes et pour la gloire de l'Ecole, si d'après un plan régulier et bien combiné, elle parvenait à se procurer les traductions des anciens auteurs grecs et latins, dans lesquelles les Professeurs de l'Ecole auraient concouru avec les plus savants littérateurs pour établir la véritable texte, le rendre fidèlement en y ajoutant les notes nécessaires ou intéressantes que leur fourniraient l'étude plus immédiate de ces auteurs." This is an excerpt of the article of Langins, who cites from the minutes of the meeting of the Council of Ecole Polytechnique on June 8, 1804 ("procès-verbal du Conseil de l'Ecole polytechnique du 19 prairial an XII"). 
$1804, \mathrm{v}-\mathrm{vi})^{15}$

At the end of this report, Lagrange and Delambre mentioned that the translator had begun another translation of Archimedes' work and announced their intention to continue supporting Peyrard for the remainder of his project (Peyrard 1804, vi). Certainly, both Lagrange and Delambre were supporters of Peyrard. Delambre continued cooperating with Peyrard on the translation of Archimedes. He not only gave advice to Peyrard on his translations but also provided his own demonstrations, which were inserted among Peyrard's commentaries on Archimedes. In particular, Delambre wrote an article titled L'Arithmétique des Grecs (The Arithmetic of the Greeks), which was attached to this work by Peyrard. ${ }^{16}$

Lagrange, as we have seen, supported a general translation project of mathematical works by the ancients. He knew Peyrard personally since they had worked together in the committee for organizing public education during the French Revolution and become colleagues at the Ecole Polytechnique. Peyrard's interest in and knowledge of mathematics and ancient Greek had taken root earlier in his life (Langins 1989, 7). But it was only after Peyrard entered the Ecole Polytechnique that he formulated the project of systematically translating the mathematical works of the ancient Greeks. A possible explanation for his decision to undertake this project is the influence and encouragement of Lagrange. They have talked with each other and shared their common interest in these Greek texts on occasions such as the meeting of the members of the Council of the Ecole Polytechnique.

In 1814, Peyrard published the first volume of the trilingual version of Euclid's Elements in Greek, Latin, and French, based on the manuscripts preserved in the imperial library of Paris at the time. One of these manuscripts, later known as the "Vaticanus 190," was particularly precious and had been conserved in the Library of the Vatican before it was taken to Paris as a trophy of the French Revolutionary campaigns in Italy. ${ }^{17}$ The following two volumes appeared respectively in 1816 and 1818. In his preface to this three-volume work, the only contemporary scholar that Peyrard mentioned was Lagrange, who had often told him that "Geometry is a dead

15 "on peut conclure au moins de leur opinion, que le citoyen Peyrard a fait une chose utile en traduisant fidèlement un ouvrage dont nous n'avons pas eu de traduction exacte depuis plus de deux cents ans, et, dont les bonnes éditions, soit grecques soit latines, sont assez rares, et à la portée de peu de savants, sans compter les difficultés des deux langues, qui diminuent encore assez considérablement le nombre des lecteurs."

16 It is worth mentioning that this article was later included in the several textbooks on arithmetic comprising Garnier's treatise of arithmetic.

17 It is interesting to mention a review published in the 11th volume of the journal Dublin Review in 1841. The author (no name indicated) mentioned that Monge had scoured the city of Rome "with the eye of a hawk and the nose of a greyhound for spoil" and found the manuscript, and then sent it to Paris (Anonymous 1841, 339). 
language; those who do not study Geometry in Euclid do the same thing as those who want to learn Greek and Latin, through reading the modern works written in these two languages" (Peyrard 1814, ix).18 By citing these words, Peyrard meant to justify his translation of Euclid, pointing to the fact that the geometry of the ancients was appreciable even for a mathematician as great as Lagrange. This reference further suggests that Peyrard had followed the urgings of Lagrange about the importance of translating these ancient Greek texts and that the two had communicated with each other about these precious works. It shows how Lagrange, who regretted the widespread ignorance of Euclid's geometry (especially on the Continent), played a positive role in the realization of Peyrard's project of translating the ancient mathematical texts and making them easily available.

Besides Peyrard, Nicolas Halma was among the authors who contributed to the effort of making Greek texts available shortly after the Revolution. Interestingly, he also had a connection with the Ecole Polytechnique as well as with Lagrange. Halma was born in 1755 in the North of France. He was trained in medicine and became a clerk soon thereafter. The first publication of Halma was a treatise titled L'Education (Education) in 1791. He had practiced teaching by giving courses on mathematics and geography for many years during the French Revolution, and had played an important role in the reform of public education in his native city. He arrived in Paris shortly thereafter, in 1795, and became the secretary of the Council of the Ecole Polytechnique, where he began to pursue a scientific life. ${ }^{19}$

The work that earned Halma a reputation was his translation of Almagest, or Mathematical Composition, by Ptolemy. It is worth mentioning that this work, appearing in French for the first time, was considered the best edition of Ptolemy by the English mathematician Auguste De Morgan (De Morgan 1847, 84). Halma published the first volume of this work in 1813 with the long title Mathematical Composition of Claude Ptolemy, Translated for the First Time from Greek to French, on the Original Manuscripts of the Imperial Library of Paris, and Followed with notes of M. Delambre. ${ }^{20}$ Again we see the name of Delambre, who had appeared as a collaborator of Peyrard on the translation of Archimedes. In addition, Halma mentioned Lagrange (in the exact words of Halma's work, "the author of Théorie des fonctions analytiques") in the preface as the figure who had opened the way for the work he was now presenting, and to whom posterity would be indebted for his advice and encouragement (Halma 1813, vi). This evidence illustrates

18 “[M. Lagrange] me répétait souvent que la Géométrie était une langue morte; que celui qui n'étudiait pas la Géométrie dans Euclide, faisait la même chose que celui qui voudrait apprendre le grec et le latin, en lisant les ouvrages modernes écrits dans ces deux langues."

19 Aujac (1990) gives a more detailed biography of Nicolas Halma.

20 “Composition mathématique de Claude Ptolémée, traduite pour la première fois du grec en français, sur les manuscrits originaux de la bibliothèque impériale de Paris, et suivie des notes de M. Delambre." 
well the role that Lagrange played in Halma's project of translating ancient Greek texts. It is possible that Halma got in contact with Lagrange when both were at the Ecole Polytechnique. Halma finished the translation of the second volume of Ptolemy in 1816, and went on to publish a translation of the work of Theon, a commentator on Ptolemy.

Besides the translations of ancient Greek texts in mathematics and astronomy, a bunch of other ancient texts in the sciences were translated into French between 1804 and 1818 due to the efforts of this group of scholars. It is thus interesting to inquire into their motivations for introducing and translating these great scientific works into French. Mainly, there are three explanations for the emergence of the translations and republications of these texts. First, some scholars at the time had expressed regrets that good versions of the classic works were inaccessible to most savants. In particular, Lagrange had shown great interest in the ancient texts in his lectures both at the Ecole Normale of the Year III and at the Ecole Polytechnique. He gave strong support and advice to his colleagues at the Ecole Polytechnique in their project of translating such important texts. Second, these savants looked to the rigor that characterized the ancients' demonstrations as an ideal. For this reason, some contemporary mathematicians had a taste for the method of the ancients and regarded the work of Euclid as the best in this sense, especially in England. On the Continent, there was also an attempt at the turn of the nineteenth century to "revive the taste for rigorous demonstrations." The publication of Adrien-Marie Legendre's Eléments de géométrie (Elements of Geometry) in 1794 reflected such an attempt (Delambre 1810, 34).

Third, the value of the ancient works lay in the knowledge and the methods demonstrated by the ancient authors, which could be of use to contemporary scholars. In the opinion of Halma, in order to advance the sciences, it was useful to translate and interpret the ancient works into a familiar or vulgar language. To justify this opinion, Halma cited some of the great savants of his day who shared this opinion. The astronomer Jérome Lalande (1732-1807), as Halma mentioned in his work, felt obliged to "borrow from the great work of Ptolemy all the ancient observations on which the research of the celestial movements was founded" (Halma 1813, vj). He also cited the astronomer and mathematician Jean-Sylvain Bailly (1736-1793), who had commented on Ptolemy's Almagest:

This work, says Bailly, made the communication between ancient and modern astronomy. Important observations through their antiquity are preserved [in this work]. [. . .] This book, besides, contains the methods or the germ of the methods that are still practical today. (Halma 1813, vj) $)^{21}$

21 “Cette ouvrage, dit Bailly, fait la communication entre l'astronomie ancienne et la moderne. Des observations importantes par leur antiquité y sont conservées. [. . .] Ce livre d'ailleurs contient les méthodes ou le germe des méthodes qui sont encore pratiquées aujourd'hui." 
Halma believed that a work such as his translation of Ptolemy's Almagest would "instead of slowing down the progress of science, lighting it up in its development" (Halma 1813, v).22 This reveals the true motivation of some mathematicians at the beginning of the nineteenth century, notably Lagrange. As we have seen in this section, under the influence of Lagrange and with his support, several scholars revisited the ancients' mathematical works and implemented a project of translating and diffusing such texts, in particular those in the sciences. The motivation of Lagrange and his followers in doing so was to propel the development of mathematics. Lagrange believed that the methods practiced by the ancients could be restudied and reused in their own work. In the next section, I will look at Lagrange's treatment of the history of mathematics in order to reveal what role history played in his mathematical research.

\section{History of mathematics as a methodology for Lagrange}

Historians have already taken note of Lagrange's interest in the history of mathematics, which is illustrated by the way he introduced historical discussions and examinations into his mathematical works. U. Bottazzini has pointed out that Lagrange's concern for history already appeared in his early papers. For instance, in "Recherches sur la nature et la propagation du son" (Study on the Nature and the Propagation of Sound) of 1761, Lagrange presented his own solution to the problem of vibrating strings only after a lengthy discussion of earlier contributions to this problem. U. Bottazzini also suggests that in another paper by Lagrange, "Réflexions sur la resolution algébrique des equations" (Reflections on the Algebraic Solutions of Equations) of 1772, the historical investigation served not only as background but also as a guideline for Lagrange's research, and that a detailed examination of historical methods and approaches allowed new mathematical concepts to arise in a natural way (Bottazzini 2002, 72-73).

In fact, Lagrange's typical style was remarked upon by one of his contemporaries, Guillaume Libri (1803-1869), an Italian mathematician, historian, and bibliophile. Libri was reputed for his four-volume work Histoire des sciences mathématiques en Italie (History of the Mathematical Sciences in Italy), in which he used thousands of excerpts from manuscripts, letters, and books by Galileo, Fermat, and Descartes as original sources. In a review by Libri of an article by Michel Chasles (1793-1880), titled "Aperçu historique sur l'origine et le développement des methods en géométrie" (Historical Outline on the Origin and the Development of the Methods in Geometry) and published in the Journal des savants (Journal of Savants), Libri discussed various approaches to the history of the sciences and highlighted Lagrange's style in particular:

The history of science can be treated in different ways. Most writers have made clear the

22 "au lieu de rallentir les progrès de la science, l'éclairer au contraire dans sa marche." 
sequence of and connection between the most glaring discoveries, adding sometimes the biography of the most famous savants. Others, and M. Chasles belongs to this class, have applied themselves to displaying in an abstract way the progress of the human mind, without dealing with the men who could have contributed [to this progress]; finally, recently, some have tried to write conjointly the history of ideas and that of men, in order to allow them to shed light on one another, and at last to be able to explain the scientific and literary vicissitudes of the nations. We conceive that the history of a science, especially that of mathematics, whatever the way of dealing with it might be, should also necessarily include the discussion and the comparison of the methods, which are the necessary elements of all the discoveries: however, until now nobody has made attempts to devote their work to these issues, and we possess in this respect only particular works on this or that question. Among the geometers who knew best how to make comparisons and, so to speak, the anatomy of the methods, we should in particular cite Lagrange, whose historical analyses are genuine models. (Libri 1839a, 494-495) ${ }^{23}$

This statement by Libri is very interesting. On the one hand, it gives us a picture of how people reconstructed the history of science in the eighteenth and nineteenth centuries; on the other hand, it remarks on the emergence of a new way of treating the history of science, in particular the history of mathematics, in the first decades of the nineteenth century. From his perspective, the discussion and comparison of the methods used throughout history should play an important role in historical works on mathematics. This is because, in his view, a deep study of such methods would significantly contribute to the subsequent progress of the sciences and thus deserved all the attention of geometers. ${ }^{24}$ Lagrange, as Libri emphasized, was the one who best knew "the anatomy of the methods" (Libri 1839a, 495).

To illustrate his opinion, Libri recounted how Lagrange had solved a difficult problem of indeterminate analysis in his youth-using a method that allowed him to diminish successively the coefficients of unknowns - and how he had repeatedly applied the same idea to other questions later on. Libri claimed that, in this case, the germ of one of

23 “L'histoire des sciences peut être traitée de différentes manières. Le plus grand nombre des écrivains ont fait connaître la suite et l'enchaînement des découvertes les plus éclatantes, en y joignant parfois la biographie des plus illustres savants. D'autres, et $\mathrm{M}$. Chasles appartient à cette classe, se sont appliqués à exposer d'une manière abstraite l'avancement de l'esprit humain, sans s'occuper des hommes qui pouvaient y avoir contribué; enfin, dans ces derniers temps, on a essayé de faire marcher de front l'histoire des idées et celle des hommes, pour les éclairer l'une par l'autre, et afin de pouvoir expliquer les vicissitudes scientifiques et littéraires des nations. On conçoit que l'histoire d'une science, des mathématiques spécialement, de quelque manière qu'on la traite, doit nécessairement renfermer aussi la discussion et la comparaison des méthodes, qui sont les éléments nécessaires de toutes les découvertes: mais jusqu'à présent on n'avait jamais tenté de faire un ouvrage spécial sur cette matière, et l'on ne possédait, à cet égard, que des travaux particuliers sur telle ou telle question. Parmi les géomètres qui ont su le mieux faire la comparaison, et pour ainsi dire l'anatomie des méthodes, on doit surtout citer Lagrange, dont les analyses historiques sont de véritables modèles."

24 Mathematicians in the eighteenth century were usually referred to as geometers. 
Lagrange's most brilliant analytical discoveries had been a very simple remark. He also argued that it would be easy to find similar examples and to show that in a great number of cases, the most important results were due only to the known methods. It was thus convincing for Libri that the repeated and reasonable application of all the known methods in mathematics to unresolved questions would certainly yield new results and highlight hitherto unknown relations and analogies (Libri 1839a, 499-500).

Therefore, as Libri considered, the value of a historical text for a nineteenth-century mathematician lay in the useful methods that the text contained, which could be applied to unsolved problems. The case of the manuscripts of Fermat served as proof for this argument. In another article in the same journal, Libri informed readers about the unpublished manuscripts of Fermat that had just been found in the collection of the French mathematician Louis-François Antoine Arbogast (1759-1803). Since Libri intended to arouse others' interest in the manuscripts of Fermat, whom he considered to be one of the most important geometers that ever lived, he began to explain why they should be treasured by his contemporaries.

According to Libri, in the published letters of Fermat, a great number of excellent results and theorems had been found and recognized, but Fermat's demonstration of the theorems appeared neither in the letters he addressed to his contemporaries nor in his marginal notes (Libri 1839b, 539-540). Also, for Libri, Fermat was the only mathematician who had not been surpassed by those who succeeded him. Libri claimed that even Euler and Lagrange, who went to great pains to shed light on Fermat's theorems on indeterminate analysis, could not compensate for the methods that Fermat had possessed. Evidently, the manuscripts that Fermat left behind were revealing, as Libri tried to convince his contemporaries.

Another interesting work by Fermat that Libri mentioned was Fermat's annotations on the Arithmetica by the Alexandria mathematician Diophantus, based on the edition of Bachet, which appeared in 1621. As Libri mentioned, Fermat wrote down his observations as well as theorems related to the theory of numbers in the margins of this book (Libri 1839b, 542-543). For this reason, Fermat's manuscripts were all the more precious to those curious about Diophantus's methods of solving indeterminate problems. And Lagrange was indeed curious.

In fact, Libri referred to an impressive project by Lagrange to produce a new edition of the work of Diophantus. As Libri indicated, Lagrange specifically regarded Fermat's remarks on Diophantus as the most precious of Fermat's writings, and proposed to clarify them in a new edition of Diophantus. Libri thus mentioned Lagrange's project in a footnote in his article. As Libri indicated, Lagrange's proposal for the project was preserved in manuscript form in the library of the institute. R. Rashed has done a study on Lagrange's proposed edition of Diophantus, as I mentioned at the beginning of this paper. Considering that this manuscript not only provides a piece of evidence for Lagrange's genuine interest 
in the ancient Greek texts on mathematics but also reveals Lagrange's intention and motivation to study these historical texts, it makes sense to quote it at length:

\section{Project of a New Edition of the Arithmetic of Diophantus:}

Diophantus of Alexandria flourished about the middle of the fourth century. We can regard him as the inventor of algebra; at least it is certain that his books on arithmetic questions are the oldest work that we have on this science; but when this work appeared in Europe, algebra had already been made known by the writings of Leonard of Pisa [Leonardo Fibonacci, 1175-1250] and Lucas Pacioli of Burgo [1445-1517]. We are obliged to the former for having brought to us, from the Arabs, the first rules of this science around the middle of the fifteenth century, and we are obliged to the latter for having collected and explained them in the first treatise that was printed on this material, which appeared in 1494 in Venice under the title of Summation of Arithmetic and Geometry. The work of Diophantus was found in the Vatican Library around the sixteenth century and then published in Greek and in Latin by Xylander with some very verbose commentaries in 1575. But of the thirteen books that this work contains originally, only seven are available to us. Since then, two further editions of Diophantus appeared, of which the first was put out by Bachet of Meziriac [1581-1638] in 1621, which by far overtake that of Xylander, both by the exactitude of the translation and by the merit of the commentaries. We owe the second to the son of Fermat; it contains the commentaries of Bachet, but what's more, it is enriched by a treatise of Father Billy on indeterminate analysis, by several remarks of Fermat that we can regard as the most precious part of the writings of this great geometer that we can still read. This last edition, which is of 1670, has already become very rare, and it would be hoped that someone undertakes to provide a new edition. But in order to cut it down to what is of interest in this century, it would be fitting, in my opinion, to remove the largest part of the commentaries of Bachet, which, excellent for the time when they appeared, no longer have the same merit today, now that calculation has become so familiar to geometers. On the other hand, as Diophantus's solutions of indeterminate problems include particular artifices that are worth of all the attention of the geometers, and that are difficult to grasp in the same work of Diophantus because these solutions are purely numeric, it would be appropriate to replace the commentaries of Bachet with a short algebraic analysis of each question, which allows one to sense the spirit of the methods and their utility in other questions. At last we should add some notes, in small number, in which we indicate what has been done since then, either for perfecting the methods of Diophantus or discovering new ones, or in particular for clarifying the short remarks of Fermat and reestablishing the largest part of the beautiful theorems that are scattered there.

Such is the objective that I proposed to myself some years ago, but that other occupations have prevented me from realizing. If the Academy considers this objective to be of some importance, I ask your consent to submit in your judgement a part of the work that I have started, and which consists in the analytic expression of the work of Diophantus. Your support, if you judge it worthy, would be for me a powerful 
motivation to not give up an undertaking that appears to be of some utility to the progress of analysis. (Libri 1839b, 552-553) ${ }^{25}$

In this outline of his project, Lagrange briefly talked about the different editions of Arithmetica by the Alexandrian mathematician Diophantus, whom he considered the inventor of algebra. The long absence of a good edition of this work thus seemed regrettable to him. As precious as this work was, Lagrange intended to provide a new edition of his own. He put forward two main reasons for why a new edition was desirable. On the one hand, the last edition of this work of Diophantus, including the commentaries of Bachet and some remarks of Fermat, appeared in 1670 and had since become outdated and very rare. On the other hand, the particular artifices (techniques) that yielded the solutions to the indeterminate problems of Diophantus were valuable

25 "Projet d'une nouvelle édition de l'arithmétique de Diophante: Diophante d'Alexanderie florissoit vers le milieu du quatrième siècle: on peut le regarder comme l'inventeur de l'algèbre; du moins il est certain que ses livres des questions arithmétiques sont le plus ancien ouvrage que nous ayons sur cette science; mais lorsque cet ouvrage parut en Europe, l'algèbre y était déjà connue par les écrits de Léonard de Pise et de Lucas Pacciolo dit delBurgo. On a au premier l'obligation de nous avoir approté d'Arabie les premières règles de cette science, vers le milieu du quinzième siècle, et au second celle de les avoir rassemblées et expliquées dans le premier traité qui ait été imprimé sur cette matière, lequel a paru en 1494 à Venise, sous le titre de Summa de arithmetica et geometria. L'ouvrage de Diohante fut trouvé dans la bibliothèque Vaticane au milieu du seizième siècle, et ensuite publié en grec et en latin par Xilander [Xylander] avec des commentaires très prolixes, en 1575. Mais des treize livres que cet ouvrage contenoit originairement il ne nous en est parvenu que sept. Depuis il a encore paru deux autres éditions de Diophante, dont la première a été donnée par Bachet de Méziriac, en 1621, et l'emporte beaucoup sur celle de Xilander, tant par l'exactitude de la traduction que par le mérite des commentaires. On doit la seconde à M. Fermat le fils; elle contient les commentaires de Bachet, mais elle est de plus enrichie d'un traité du père Billy sur l'analyse indéterminée, de plusieurs remarques de Fermat qu' on peut regarder comme la partie la plus précieuse des écrits de ce grand géomètre qui nous soit parvenue. Cette dernière édition, qui est de 1670, est déjà devenue très rare, et il seroit à souhaiter que quelqu'un entreprît de nous en procurer une nouvelle; mais pour la réduire à ce qu'elle pourroit contenir d'intéressant dans ce siècle, il conviendroit, ce me semble, de la débarrasser de la plus grande partie des commentaires de Bachet, lesquels, excellents pour le temps où ils ont paru, n'autroient plus le même mérite aujourd'hui que le calcul est devenu si familier aux géomètres. D'un autre côté, comme les solutions des problèmes indéterminés de Diophante renferment des artifices particuliers qui méritent toute l'attention du géomètre, et qu'il est difficile de saisir dans l'ouvrage même de Diophante à cause que ces solutions sont purement numériques, il seroit à propos de remplacer les commentaires de Bachet par une courte analyse algébrique de chaque question, qui fit sentir l'esprit des méthodes et de leur utilité dans d'autres questions. Enfin il faudroit y ajouter quelques notes, en petit nombre, dans lesquelles on indiqueroit ce qui a été fait depuis, soit pour perfectionner les méthodes de Diophante ou en découvrir de nouvelles, soit surtout pour éclaircir les courtes remarques de Fermat, et restituer la plus grande partie des beaux théorèmes qui y sont répandus. Tel est l'objet que je m'étois proposé il y a quelques années, mais que d'autres occupations m'ont empêché de remplir. Si l'Académie trouve cet objet de quelque importance, je la prie de me permettre de soumettre à son jugement une partie du travail que j'avois commencé, et qui consiste dans l'exposition analytique de l'ouvrage de Diophante. Son suffrage, si elle l'en juge digne, sera pour moi un puissant motif de ne pas abandonner une entreprise qui paroit pouvoir être de quelque utilité aux progrès de l'analyse." 
and deserved the attention of contemporary geometers. What interested Lagrange and what he thought should interest other mathematicians were precisely the methods or artifices used by Diophantus.

However, since the solutions of Diophantus were all numerical, it would require much time and effort to acquire the methods that Diophantus had used. Therefore, Lagrange proposed removing the commentaries of Bachet from the new edition of Diophantus's work because, as the culture of geometers had changed, they were no longer needed. Also, it occurred to Lagrange to add an algebraic analysis to each question in Diophantus's Arithmetica, which would allow readers to better grasp the essence of the method. What's more, Lagrange designed a project to improve on the methods of Diophantus or to discover new methods. Furthermore, one of his aims was to illuminate Fermat's short remarks on Diophantus and to reestablish the majority of the beautiful theorems that were spread throughout Fermat's annotations, using a number of notes to indicate what had been done until then.

At the time he proposed this project, Lagrange had already carried out much of the work it entailed. The part of the work he had done consisted of an "analytical exposition" of Diophantus's work, which means that he made Diophantus's solutions more abstract or reformulated them in a more algebraic way. According to Libri, who mentioned Lagrange's project in his article, Lagrange's manuscript consisted of an eleven-page analysis of the first four books of Diophantus. But no mention is made of when the project proposal was composed by Lagrange. In Libri's opinion, it had been submitted to the Academy of Berlin. Also, Libri mentioned that Lagrange cited the French translation of Euler's Elements of Algebra in the margin of his manuscript (Libri $1839 \mathrm{~b}, 553)$. This gives a hint as to the probable time of the beginning of Lagrange's project on Diophantus.

Lagrange had stayed in Berlin from 1766 until 1787. Around 1770, Lagrange became very interested in indeterminate analysis, which in his view had not advanced much over the previous century, the exception being the discoveries by Euler. He thus invited Jean Bernoulli (1744-1807) to translate Euler's Elements of Algebra, which comprised two parts, one on determinate analysis and another on indeterminate analysis. Lagrange contributed his own addition to the part on indeterminate analysis and included it in the French translation of Euler's book. His intention was to present a complete methodological treatise on indeterminate analysis, which included and explained what were clearly the most important rules known at that point for how to solve indeterminate problems, something that no one had done before him. Coincidentally, it was also around this time that Lagrange conceived his project of a new edition of Diophantus's work and made his proposal to the Academy of Berlin. Without a doubt, these efforts by Lagrange, whether to produce a new edition of Diophantus or to contribute to Euler's book, were all made with the purpose of improving his work on 
indeterminate analysis.

Afterwards, Lagrange kept up his interest in ancient mathematical works. He still had the intention to produce a new edition of Diophantus, as he expressed his admiration for Diophantus and his work while teaching arithmetic at the Ecole Normale of the Year III and at the Ecole Polytechnique, as I mentioned above. At the Ecole Polytechnique, he took part in the promotion of a larger project of translating the mathematical works of the ancient Greeks, such as those of Euclid and Archimedes, through cooperation with Peyrard, Delambre, and Halma. A translation of Diophantus was expected to be published, as Peyrard had invited Thévenot, a former professor at the Ecole des Ponts et Chaussées, to carry out this work (Peyrard 1807, xxxviij). But it never appeared, and nor did Peyrard's translation of Apollonius. Indeed, it became difficult for Peyrard to continue his work after he was laid off in 1804 from the Ecole Polytechnique. Another explanation could be that during his last years and after his death in 1813, Lagrange's support was not strong enough for the project to carry on.

So far, we have seen that Lagrange had a great interest in the history of mathematics and made many efforts to advance the vulgarization and diffusion of important ancient Greek works. His interest was in certain principles or methods employed by the ancients. Moreover, Lagrange had much appreciation for the rigor of the ancients, which translated into a commitment to the pursuit of rigor and constituted one of his epistemic values in his own mathematical work. He undertook to rigorize analysis, an issue to which he devoted much of his career. When he taught differential calculus at the Ecole Polytechnique, he claimed to bring all the rigor displayed in the demonstrations of the ancients to the solutions of geometrical problems involving differential calculus (Lagrange 1797, 6).

\section{History of calculus and Lagrange's epistemological values}

Remarkably, Lagrange often discussed an issue in terms of history before he began to deal with it mathematically. As M. T. Borgato suggests, the insertion of long introductions and historical notes was meant to create a link with the research of the past and present modern theories as the final stage of their evolution (Borgato 2012, 41). She also points out (as cited by U. Bottazzini) that for Lagrange, "historical investigation was a necessary preliminary to any original work or systematization" (Bottazzini 2002, 70). ${ }^{26}$ This section will look to Lagrange's history of calculus as a demonstration of the function of history in Lagrange's mathematical texts. Meanwhile, it reveals the four epistemological values pursued by Lagrange in his works on the subject of calculus and its applications.

26 The quotation from M. T. Borgato's article, which was written in Italian, was translated by U. Bottazzini. See also Borgato $(1989,108)$. 
While Lagrange was teaching analysis at the Ecole Polytechnique from 1795 to 1799 , he contributed two important publications, namely Théorie des fonctions analytiques of 1797 and Leçons du calcul des fonctions of $1801 .{ }^{27}$ Both were published two times. These two books were devoted to so-called infinitesimal analysis, or higher analysis. But Lagrange named it the theory or the calculus of functions, as the titles of the books indicate. In these two books, Lagrange proposed a new method of presenting the principles of differential calculus. He claimed on the cover of the Théorie that this method "[could be] freed from all the consideration of infinitely small quantities, vanishing quantities, limits and fluxions, and reduced to algebraic analysis of finite quantities."28 This claim shows his rejection of his predecessors' conceptualization, which he would explain through a historical narrative of the methods that had been employed to resolve issues of infinitesimal calculus. As a matter of fact, one of Lagrange's reasons for writing these two treatises was to put an end to the trouble that infinitesimals caused, which his contemporaries had become aware of.

The use of infinitesimals helped eighteenth-century mathematicians yield many results both in mathematics and its applications. However, in concentrating primarily on the applications, they showed few interest in the issue of the rigor of their demonstrations. The results could be justified by their application to physics. Although Bishop Berkeley's attack on the foundations of calculus confronted the "analysts" 29 with philosophical questions, the issue of rigor with regard to the foundations of calculus was not the "central concern" for most eighteenth-century mathematicians, as J. Grabiner has argued in her book The Origin of Cauchy's Rigorous Calculus (Grabiner 1981, 18). N. Guicciardini has also pointed out that "the problems of foundations did not exist in the eighteenth century as we understand it nowadays," and that "mathematicians were more occupied with defining the 'principles' of calculus" (Guicciardini 1989, 38). ${ }^{30}$

It thus seems that the case of Lagrange, who returned several times during his mathematical career to the issue of the foundation of calculus, is the exception. As early as 1772, Lagrange had proposed an alternative to the method of infinitesimals in his paper "Sur une espèce de calcul relatif à la différentiation et l'intégration des quantités

27 For the sake of convenience, these two books will be abbreviated as Théorie and Leçons hereafter.

28 It is written on the cover of the Théorie: "Théorie des fonctions analytiques, contenant les principes du calcul différentiel, dégagés de toute considération d'infiniment petits, d'évanouissans [évanoussants], de limites et de fluxions, et réduit à l'analyse algébrique des quantités finies."

29 Berkeley used "analysts" to refer to the secular mathematicians, especially those who practiced and had faith in infinitesimal or fluxional calculus at the time. To learn more, consult Berkeley (1734) and Grattan-Guinness (1969).

30 To be more precise, according to Guicciardini, the eighteenth-century mathematicians "were concerned with the ontological status of the objects of the calculus and with the correctness of the methods of calculus according to the standards of Aristotelian logic." 
variables" (On a Type of Calculation Related to the Differentiation and the Integration of Variable Quantities). Although this paper did not refer to the foundations of differential calculus in those exact words, he did introduce new ideas which concerned fundamental issues on the topic. He put forward in this paper the theory of the development of functions in series and introduced the notion of derived functions, which in his view were the objects of differential calculus. Such a notion seemed to him the clearest and simplest, and independent of all metaphysics as well as of the theory of infinitely small quantities and vanishing quantities (Lagrange 1772, 443). He used this notion first to demonstrate the Theorem of Taylor and then to deduce a beautiful formula that would later serve as one of the basic theorems of a new subject developed by English algebraists: the calculus of operations. ${ }^{31}$ However, Lagrange did not keep on applying this notion to deduce and verify the many results that had previously been established by the method of infinitesimals, since it was not the purpose of this paper. This would not occur until much later, while teaching a course on analysis at the Ecole Polytechnique, where he developed his theory or method of derived functions and attempted to found differential calculus on this method as well as to connect it to algebra.

Another of Lagrange's efforts to give calculus a solid foundation while he lived in Berlin involved the 1784 proposition of a prize for a clear and precise theory of infinity in mathematics. The use of infinity introduced self-contradictory notions in the eyes of some great analysts at that time. The Academy of Berlin, in posing the question to all mathematicians, wished to get responses that could explain how so many theorems had been deduced from a contradictory supposition and indicate a certain, clear, and suitable substitute for the principle of infinity. Additionally, the academy expected the issue to be treated in a way that fulfilled the criteria of generality, rigor, clarity, and simplicity (Anonymous 1786, 12-13; Anonymous 1788, 8).

Indeed, Lagrange played a decisive role in the proposition of the prize, as he was then the director of the department of mathematics at the academy. J. Grabiner also claims that it was Lagrange who suggested proposing the question concerning the foundations of calculus (Grabiner 1981, 41). Moreover, according to C. C. Gillispie and A. P. Youschkevitch, the submissions for the prize were ultimately examined by the class of mathematicians under the presidency of Lagrange (Gillispie and Youschkevitch 1979, 234-235). More evidence will be given to demonstrate Lagrange's leading role in this event when I show how Lagrange's concern for the foundation of calculus later manifested in his course of analysis at the Ecole Polytechnique.

The teaching of analysis at the Ecole Polytechnique provided an occasion for him to reinitiate his research in mathematics, since he had long been inactive and seemed to

31 For more information of the history of the calculus of operations, see Koppelman (1971). 
have lost his enthusiasm for the subject (Delambre 1867, xxxvii; Belhoste 2014, 27). It also allowed him to return to the problem of the foundations of differential calculus, which had intrigued him for a long time. In Théorie, Lagrange indicated the "particular circumstance" in which he found himself engaged in developing the general principles of analysis (Lagrange 1797, 5). He thus recalled the ideas that he had developed in the paper of 1772 with respect to differential calculus. The particular situation of teaching analysis at the Ecole Polytechnique prompted him to reconsider his former ideas, which consequently led to the publication of Théorie. As he emphasized, it was only for the sake of students and people who studied this branch of analysis that he decided to publish Thérie. We thus see that a concern for education occupied an important place in Lagrange's works on analysis, namely Théorie and Leçons. We will also see that Lagrange pursued certain standards, or epistemological values, in these two works for the benefit of beginners.

Recall that in its proposition of a prize in 1784, the Berlin Academy (or rather Lagrange) was looking for a work which met the four standards of generality, rigor, clarity, and simplicity. It was precisely these four epistemological values that he embraced in Théorie and Leçons, in which he dealt with the issue of the foundations of differential calculus. According to these values, he judged the methods that had been employed by his predecessors, selecting those on which he would found differential calculus. And it was through a historical narrative at the beginning of both Théorie and Leçons that he achieved these ends.

As I argued previously, the history of mathematics served as a guide or methodology for Lagrange in solving mathematical problems. In the following, I will show how Lagrange, through an examination of the history of calculus, came to the method that would allow him to fulfill all four epistemological values in his presentation of the principles of differential calculus.

Both in Théorie and Leçons, Lagrange provided historical accounts of the methods that had been employed before him to present the principles of differential calculus. In this account, he pointed out their weaknesses and proposed a new method, which in his view removed the difficulties confronted by his predecessors and met the four standards.

Lagrange's examination began with the first geometers-Leibniz, the Bernoullis, l'Hôpital, and others - who had founded differential calculus on the consideration of infinitely small quantities of different orders. Moreover, they regarded and treated as equal those quantities which differed from one another by an infinitely small amount. In Lagrange's view, their method, although general, had not properly demonstrated the principles of this branch of analysis (Lagrange 1797, 2-3). In other words, for Lagrange, they had not treated analysis with rigor and clarity. Then, Lagrange spoke of Euler and d'Alembert, who had sought to make up for the defects of Leibniz's work. Lagrange 
stated that Euler had tried to show, through particular applications, that the difference of infinitely small quantities should be zeros. D'Alembert, for his part, had shown that their ratios were nothing but the limits of the ratios of the finite or indefinite differences. Concerning these ideas, Lagrange found them "not clear enough to serve as a principle of a science, for which certitude should be founded on evidence, and above all [not clear to] be presented to beginners" (Lagrange 1797, 3). ${ }^{32}$ This assessment by Lagrange of Euler's method reflects his emphasis on clarity as one value or standard that he followed in his work on mathematical analysis. It also reflects his concern for students and beginners in composing this work.

Newton, Lagrange stated, had considered mathematical quantities as being generated by movement in order to avoid the supposition of infinitely small quantities. Accordingly, in Newton's method of fluxions or fluxional calculus, quantities are rendered as speeds. Firstly, in Lagrange's view, it was strange to introduce movement into mathematical calculations whose objects should only be algebraic quantities; what's more, for Lagrange, the meaning of the speed of a point at each instant is not clear. It thus seemed difficult to him to rigorously demonstrate the method of fluxions. Later, Newton improved on his method in his Principia, introducing the method of last ratios of vanishing quantities. This method, Lagrange thought, still did not get rid of the obscurity. In Lagrange's view, this method, like the method of limits, offered no clear and precise way to conceive of a ratio of two quantities that would both become nulls at the same time (Lagrange 1797, 3-4).

As Lagrange continued the historical discussion, he showed his appreciation for the work on analysis of the English mathematician John Landen (1719-1790). The latter did not follow Newton's method of fluxions like all the other English mathematicians and instead proposed a new method in his 1764 book titled The Residual Analysis: A New Branch of the Algebraic Art. In Lagrange's opinion, Landen's method, which was "purely analytical" for him, avoided the use of infinitely small quantities and of vanishing quantities. For this reason, Lagrange found that it rendered differential calculus more rigorous, but at the cost of methodological simplicity and facility for the operations (Lagrange 1797, 4-5).

Hence, Lagrange abandoned all the different ways that mathematicians throughout history had conceptualized differential calculus or deduced results in this subject. To him, they were lacking in either clarity, simplicity, or rigor. After his analysis of the different methods that had been used in differential calculus, Lagrange concluded:

These variations in the mode of establishing and presenting the principles of differential calculus, and even in the demonstration of this calculus, show, it seems to me, that we

32 “[Cette idée n'est] pas assez claire pour servir de principe à une science dont la certitude doit être fondée sur l'évidence, et sur-tout pour être présentée aux commençans." 
had not yet grasped the veritable theory, though we had found at first the simplest and easiest rules for the mechanism of the operations. (Lagrange 1797, 5) ${ }^{33}$

Therefore, for Lagrange, all these different ways were just flawed variations of the "veritable theory," which had not been found before him. One wonders what Lagrange meant by "veritable theory." Although he did not give an explicit indication, he implied what the "veritable theory" was by turning directly thereafter to the theory of the development of functions in series that he had proposed in his paper of 1772 . He claimed that this theory contains the "true principles" of differential calculus and detached it from all considerations of infinitely small quantities and limits (Lagrange 1797, 5).

As to this method, Lagrange stated that Newton was the first to employ series in his Principia, when solving a problem related to differential or fluxional calculus. It was strange to Lagrange that the geometers before him had not favored this theory as a way to found differential calculus. In particular, he wondered how Newton, who was the inventor of the method of series, could have missed this. Tracing the history of this issue, Lagrange figured out the reason why this method had not been favored by the geometers. In his view, Newton later abandoned the method of series because of a mistake made in its application, which was pointed out by Jean Bernoulli (1667-1748) and subsequently Nicolas Bernoulli (1687-1759). Newton, without replying to either of the two, thus presented in the second edition of the Principia a different solution to the same problem, using the same method he used for differential calculus. However, for Lagrange, the mistake did not come from the method itself, but rather from the fact that Newton had not taken into account all the relevant terms in the concern.

Through this historical examination, Lagrange explained why the method of series had not been opted for by his predecessors and defended this method. It also reveals that, while Lagrange was not the inventor of the method of series, he was the one who advocated establishing differential calculus on this method and applying it to problems of geometry and mechanics. Certainly, Lagrange created new notions and introduced innovative ideas, such as the notion of derived functions, in his works of analysis. However, it was through a historical examination of methodology that he found the method of series to be most suitable for presenting the principles of differential calculus. In Leçons, in which he provided another historical discussion on the subject of differential calculus, Lagrange clarified how he saw through the methods that had previously been employed and discovered their common element:

33 "Ces variations dans la manière d'établir et de présenter les principes du calcul différentiel, et même dans la démonstration de ce calcul, montrent, ce me semble, qu'on n'en avait pas saisi la véritable théorie, quoiqu'on eût trouvé $\mathrm{d}^{\prime}$ abord les règles les plus simples et les plus commodes pour le mécanisme des opérations." 
When we go deep into the different methods, or rather the different modes of envisioning the same method, we find that they have no other objective than to provide the way to obtain separately the first terms of the development of a function, detaching and isolating them, so to speak, from the rest of the series, because all the problems whose solution demands that differential calculus depend uniquely on these first terms. (Lagrange 1801, 9) 34

Here we can see how Lagrange used history as a tool to determine the proper method to found differential calculus. History offered a source for Lagrange to explore and guidance to help him avoid pitfalls and difficulties. While examining these methods, he judged them according to the epistemological values he pursued in his analytical work. Accordingly, he selected the method which could meet the standards of generality, simplicity, clarity, and rigor.

\section{Conclusion}

This study of J. L. Lagrange's work on the history of mathematics provides a case study of mathematical historiography at the turn of the nineteenth century. It demonstrates Lagrange's great interest in the ancient Greek texts, in particular those of Diophantus. It also sheds light on the influential role that Lagrange played in the translation and diffusion of the Greek texts by important mathematicians of his day. By means of dispensing advice and encouragement, Lagrange supported Peyrard and Halma, who respectively contributed translations of Euclid, Archimedes, and Ptolemy. Ecole Polytechnique was the place where they initiated the project, which aimed to benefit scientific education in general.

What's more, through analyzing Libri's perspective on Lagrange's historiographical style (exemplified by his project on Diophantus), this paper reveals Lagrange's motivation in working on the Greek texts. The history of mathematics served as an instrument or an approach for Lagrange to solve problems in mathematics. The history of a mathematical problem, or rather of the methods that had been used previously in dealing with the problem, allowed Lagrange to analyze and compare these methods in order to find the one best suited for solving new problems. In this sense, I suggest that the history of mathematics was more of a methodology than a pure interest for Lagrange, who saw its potential to contribute to the progress of mathematics. The investigations of the history of calculus placed at the beginning of Lagrange's two

34 "Quand on approfondit ces différentes méthodes ou plutôt ces différentes manières d'envisager la même méthode, on trouve qu'elles n'ont d'autre but que de donner le moyen d'obtenir séparément les premiers termes du développement d'une fonction, en les détachant et les isolant, pour ainsi dire, du reste de la série, parce que tous les problèmes dont la solution exige le calcul différentiel, dépendent uniquement de ces premiers termes." 
important works of analysis justifies this argument.

When Lagrange examined the history of the issue, he rejected all his predecessors' methods, which he found lacking in clarity or rigor, and sought the proper method to present the principles of differential calculus. The reasons why he rejected the previous approaches reveal the epistemological values that underpinned his analytical work, that is, generality, simplicity, rigor, and clarity. In addition, his historical study allowed Lagrange to grasp the common point of all the different methods used in the past and hence to arrive at a "true theory" that in his opinion satisfied those standards. My investigation clarifies how history was written and what part it played in Lagrange's mathematics. Thus, this paper is in line with the authors of Writing the History of Mathematics, who suggest that history has played influential roles in the making of mathematicians, and hence of mathematics itself (Dauben et al. 2002, 339).

Lastly, I wish to emphasize that the rigorization of differential calculus began with Lagrange, although he had different views and took a way different from Cauchy to this end. To a certain degree, educational concerns, as J. Grabiner has argued, constituted an impulse for this undertaking. This provides a way to understand the work of Lagrange, Cauchy, and Weierstrass, who were all active as teachers when they contributed to the movement of rigorizing differential calculus. Moreover, history was highly relevant to the issue of rigor, since the rigor demonstrated in the works of the ancient Greeks had long been an object of appreciation for mathematicians, in particular Lagrange. Indeed, one of his motivations for writing Théorie and Leçons was to bring the rigor of the ancients to contemporary work on differential calculus (Lagrange 1797, 6). This shows to what degree the Greek texts constituted a crucial resource for Lagrange's rigorization of analysis. This also helps explain why Lagrange made an effort to translate ancient mathematical texts. The techniques and artifices in the solutions and demonstrations of the ancients were beneficial to his own mathematical work. As such, this paper sheds light on how diverse activities such as translating and disseminating texts, teaching, and historical writing stimulate mathematical research.

\section{Acknowledgments}

I am thankful to the three anonymous referees. Their comments helped me improve this paper. I am also grateful to Tian Miao 田沝, who gave me great advice so that I could bolster my argument. Karine Chemla supported me unconditionally in my attempt to publish this paper. Célestin Xiaohan Zhou 周霄汉 discussed this paper with me before its submission to the journal. I owe many thanks to both of them. 


\section{References}

Anonymous. 1786. "Prix proposé par l'Académie Royale des sciences et belles-lettres pour l'année 1786." Nouveau mémoires de l'Académie Royale des sciences et belles-lettres de Berlin, Année 1784: 12-14.

Anonymous. 1788. "Prix proposé par l'Académie Royale des sciences et belles-lettres pour l'année 1788." Nouveau mémoires de l'Académie Royale des sciences et belles-lettres de Berlin, Année 1786: 8-9.

Anonymous. 1841. “(Review on) Les EEuvres d'Euclidem en Grec, en Latin, et en Français, d'après un manuscrit très ancien qui était resté inconnu jusqu'à nos jours, par François Peyrard." The Dublin Review XI:330-355.

Aujac, Germine. 1990. "Science grecque et révolution française."Bulletin de l'Association Guillaume Budé: Lettre d'humanité 49 (4): 395-409.

Belhoste, Bruno. 2011. "Paris savant: Parcours et rencontres au temps des Lumières." Paris: Armand Colin.

Belhoste, Bruno. 2014. "When an academician becomes professor: The case of Joseph-Louis Lagrange." Lettera Matematica 2 (1-2): 25-34.

Berkeley, George. 1734. The Analysts; or a Discourse Addressed to an Infidel Mathematician. London: J. Tonson.

Borgato, Maria Teresa. 1989. "La storiadellematematichenell'opera di Lagrange." In Pietro Riccardi (1828-1898) e la storiografiadellematematiche in Italia, edited by Francesco Barbieri and Franca Cattelani Degani, 107-131. Modena: Universit à degli Studi di Modena.

Borgato, Maria Teresa. 2012. "On the Historiography of Mathematics in Italy." In The Circulation of Science and Technology: Proceedings of the 4th International Conference of the ESHS, Barcelona, 18-20 November 2010, edited by Antoni Roca-Rosell, 40-45. Barcelona: SCHCT-IEC.

Bottazzini, Umberto. 2002. "Italy." In Writing the History of Mathematics: its Historical Development, edited by Joseph W. Dauben and Christoph J. Scriba, 3-44. Basel: Birkhäuser.

Dauben, Joseph W., Jeanne Peiffer, Christoph J. Scriba, and Hans Wussing. 2002. "Postscriptum." In Writing the History of Mathematics: Its Historical Development, edited by Joseph W. Dauben and Christoph J. Scriba, 3-44. Basel: Birkhäuser.

Delambre, Jean-Baptiste. 1810. Rapport historique sur les progrès des sciences mathématiques depuis 1789, et sur leur état actuel. Paris: De l'imprimerie impériale.

Delambre, Jean-Baptiste. 1867. “Notice sur la vie et les ouvrages de M. Le comte J.-L. Lagrange." In CEuvres de Lagrange tome 1:ix-li.

Dhombres, Jean, ed. 1992. L'Ecole normale de l'an III, Vol. 1: Leçons des mathématiques, Laplace-Lagrange-Monge. Paris: Éditions Rue d'Ulm. Nouvelle ed. [published online in 2012]. Accessed May 2, 2020. https:// books.openedition.org/editionsulm/442.

Gillispie, Charlie C., and Adolf P. Youschkevitch. 1979. Lazare Carnot savant et sa contribution à la théorie de l'infini mathématique. Paris: Vrin.

Grabiner, Judith V. 1981. The Origin of Cauchy's Rigorous Calculus. Cambridge: The MIT Press.

Grattan-Guinness, Ivor. 1969. "Berkeley's Criticism of the Calculus as A Study in the Theory of Limits." Janus 56:213-227.

Guicciardini, Niccolò. 1989. The Development of Newtonian Calculus in Britain, 1700-1800. 
Cambridge: Cambridge University Press.

Halma, Nicolas. 1813. Vol. 1 of Composition mathématique de Claude Ptolémée: traduite pour la première fois du grec en français, sur les manuscrits originaux de la Bibliothéque impériale de Paris. Paris: H. Grand.

Koppelman, Elaine. 1971. "The Calculus of Operations and the Rise of Abstract Algebra." Archive for History of Exact Sciences 8 (3): 155-242.

Langins, Janis. 1989. "Histoire de la vie et des fureurs de François Peyrard, Bibliothécaire de l'Ecole polytechnique de 1795 à 1804, et traducteur renommé d'Euclide et Archimède." Bulletin de la SABIX 3:2-12.

Lagrange, Joseph-Louis. 1772. "Sur une espèce de calcul relatif à la différentiation et l'intégration des qantités variables." Nouveau mémoires de l'Académie Royale des sciences et belles-lettres de Berlin: 185-221. Also CEuvres tome 3:439-476.

Lagrange, Joseph-Louis. 1797. Théorie des fonctions analytiques. Paris: L'imprimeur de la République. Tome 9 of CEuvres.

Lagrange, Joseph-Louis. 1801. "Leçons sur le calcul des fonctions." In Séances des Écoles normales, recueillies par des sténographes et revues par les professeurs. Paris: L'imprimerie du cercle-social. Tome 10 of CEuvres.

Libri, Guillaume. 1839a. “Aperçu historique sur l'origine et le développement des méthodes en géométrie, particulièrement de celles qui se rapportent à la géométrie moderne." Journal des savants: 493-505.

Libri, Guillaume. 1839b. “Des manuscrits inédits de Fermat." Journal des savants: 539-561.

Montucla, Jean-Etienne. 1758. "L'Histoire des mathématiques." 2 vols. Paris: Chez Ch. Ant. Jombert.

de Morgan, August. 1847. Arithmetical Books from the Invention of Printing to the Present Time. London: Taylor and Walton.

Oliveira, Agamenon. 2013. "Lagrange as a Historian of Mechanics." Advances in Historical Studies 2 (3): 126-130.

CEuvres de Lagrange. 1867-1892. Published by the care of Joseph-Alfred Serret. 14 tomes. Paris: Gauthier-Villars.

Peiffer, Jeanne. 2002. "France." In Writing the History of Mathematics: Its Historical Development, edited by Joseph W. Dauben and Christoph J. Scriba, 3-44. Basel: Birkhäuser.

Peyrard, François. 1804. Les éléments de géométrie d'Euclide, traduit littéralement, et suivis d'un Traité du Cercle, du Cylindre, du Cône et de la Sphère; de la mesure des Surfaces et des Solides; avec des Notes. Paris: F. Louis.

Peyrard, François. 1807. CEuvres d'Archimède, traduites littéralement, avec un commentaire. Paris: François Buisson.

Peyrard, François. 1814. Les œuvres d'Euclide, en grec, en latin et en français. Vol. 1. Paris: M. Patris.

Prony, Gaspard. 1796. "Notice sur un cours élémentaire d'analyse fait par Lagrange." Journal de l'Ecole polytechnique 2: 206-208.

Quetelet, Adolph. 1839. "Notice sur Jean-Guillaume Garnier." Annuaire de l'académie royale des sciences et belles-lettres de Bruxelles 5:161-208.

Rashed, Roshdi. 1988. "Lagrange, Lecteur de Diophante." In Sciences à l'époque de la Révolution française, edited by Roshdi Roshed, 39-83. Paris: Libraire A. Blanchard.

Richard, Joan L. 2006. "Historical Mathematics in the French Eighteenth Century." Isis 97 (4): 700-713. 